\title{
Title: A New Look at Liming as an Approach to Accelerate Recovery from Acidic Deposition Effects
}

Gregory B. Lawrence* ${ }^{1}$, Douglas A. Burns ${ }^{2}$, Karen Riva-Murray ${ }^{3}$

*Corresponding author

${ }^{1}$ U.S. Geological Survey New York Water Science Center, 425 Jordan Road, Troy, New York 12180 USA; Email: glawrenc@usgs.gov

${ }^{2}$ U.S. Geological Survey New York Water Science Center, 425 Jordan Road, Troy, New York 12180 USA; Email: daburns@usgs.gov

${ }^{3}$ U.S. Geological Survey New York Water Science Center, 425 Jordan Road, Troy, New York 12180 USA; Email: kmurray@usgs.gov

Keywords: calcium depletion, recovery from acidification, watershed liming, aluminum toxicity 


\begin{abstract}
Acidic deposition caused by fossil fuel combustion has degraded aquatic and terrestrial ecosystems in North America for over four decades. The only management option other than emissions reductions for combating the effects of acidic deposition has been the application of lime to neutralize acidity after it has been deposited on the landscape. For this reason, liming has been a part of acid rain science from the beginning. However, continued declines in acidic deposition have led to partial recovery of surface water chemistry, and the start of soil recovery. Liming is therefore no longer needed to prevent further damage, so the question becomes whether liming would be useful for accelerating recovery of systems where improvement has lagged. As more is learned about recovering ecosystems, it has become clear that recovery rates vary with watershed characteristics and among ecosystem components. Lakes appear to show the strongest recovery, but recovery in streams is sluggish and recovery of soils appears to be in the early stages. The method in which lime is applied is therefore critical in achieving the goal of accelerated recovery. Application of lime to a watershed provides the advantage of increasing $\mathrm{Ca}$ availability and reducing or preventing mobilization of toxic $\mathrm{Al}$, an outcome that is beneficial to both terrestrial and aquatic ecosystems. However, the goal should not be complete neutralization of soil acidity, which is naturally produced. Liming of naturally acidic areas such as wetlands should also be avoided to prevent damage to indigenous species that rely on an acidic environment.
\end{abstract}




\section{1. $\quad \underline{\text { Introduction }}$}

Acidic deposition caused by fossil fuel combustion has degraded aquatic and terrestrial ecosystems in North America and Europe for over four decades. The widespread recognition of consequences of ecosystem acidification has led to effective political and regulatory efforts to reduce emissions and corresponding deposition of acidifying substances (Burns et al., 2011). For example, in the northeastern U.S., wet deposition of sulfur in 2010 was approximately onequarter of the level in 1980 (http://nadp.sws.uiuc.edu/; accessed Sept. 25, 2015). However, the lowering of emissions has been a gradual process and further reductions have been recommended to achieve recovery goals (Burns et al., 2011).

The only management option other than emissions reductions for combating the effects of acidic deposition has been the application of substances to neutralize acidity, most often lime, after the acids have been deposited on the landscape. Lake and stream liming was initially used as a fisheries management tool to neutralize acidic waters as a stopgap measure or in the earliest stages to simply improve water quality before acidic deposition was discovered (personal communication, H.A. Simonin, New York State Department of Environmental Conservation, retired). For this reason, liming has been a part of acid rain science from the beginning (Scheider et al., 1975) and has continued to be used for both experimental (Sterling et al., 2014) and operational purposes (Hesthagen et al., 2011; Moore et al., 2015).

With recovery of surface waters (Clair et al., 2011; Strock et al., 2014; Wright et al., 2005) and soils (Lawrence et al., 2015a) underway, and acidic deposition levels continuing to decline, liming is no longer needed to prevent further damage. The question has now become whether liming would be useful for accelerating recovery of systems where improvement has lagged. Slow chemical responses of surface waters and soils to decreasing emissions has been linked to $\mathrm{Ca}$ depletion from decades of elevated soil leaching by acidic deposition (Likens et al., 1996). The capacity of soils to replenish lost Ca under current and future emissions remains uncertain (Lawrence et al., 2015a; Lawrence et al., 2012).

Under these current conditions, liming remains a potential management option to boost the availability of $\mathrm{Ca}$ in aquatic and terrestrial ecosystems where $\mathrm{Ca}$ depletion limits the reversal of acidic deposition effects. Therefore, the objective of this review is to assess liming as a possible tool to accelerate recovery of ecosystems within the context of our current understanding of recovery processes. Because the current status of recovery is a key factor in the efficacy of liming, this article begins with a summary of the chemical recovery status of North American surface waters and soils. This assessment considers the treatment of both aquatic and terrestrial ecosystems to identify (1) the settings and application methods with the greatest likelihood of improving overall ecosystem health, and (2) the remaining questions that need to be addressed to fully weigh the benefits and drawbacks of liming as a remediation tool.

The literature on the use of liming to combat acidic deposition effects in Europe and North America is extensive. For this review we have chosen North America as the geographic focus, but include European studies with high relevance to North American conditions. 


\section{The Status of Chemical Recovery in North American Surface Waters and Soils}

\subsection{Lakes}

The most pronounced reversals of lake acidification have occurred in regions where peak acidic deposition levels were highest and where decreases were greatest. In the area surrounding Sudbury, Ontario, emissions of $\mathrm{SO}_{2}$ from metal smelters decreased from 2500 metric kilotons per year in 1960 to less than 300 metric kilotons in 2002. In response, surveys of 44 lakes in this region showed that the number of lakes with $\mathrm{pH}$ less than 5.0 decreased from 28 in 1981 to 6 in 2004 (Keller et al., 2007). However, only 14 of the lakes had a pH greater than 6.0 by 2004, the level considered sufficient for most aquatic biota (Driscoll et al., 2001). Large decreases in lake $\mathrm{SO}_{4}$ concentrations occurred, but were partially offset by decreases in base cation concentrations.

In Atlantic Canada, where deposition levels are the lowest in eastern North America, but buffering capacity is also extremely low, $\mathrm{pH}$ did not show significant changes in any of 66 lakes from 1983 to 2007 (Clair et al., 2011). The difference between base cations and acid anions (calculated acid neutralizing capacity) did increase significantly over this time period in these same lakes due to decreases in $\mathrm{SO}_{4}$ that were greater than decreases in $\mathrm{Ca}$ (Clair et al., 2011). Concentrations of Ca continued to decrease significantly through the periods of 1990 to 2007 and 2000-2007.

In the Adirondack region of New York State, arguably the region in the U.S. with the greatest impacts from acidic deposition, wet atmospheric $\mathrm{SO}_{4}$ deposition declined by approximately three-fourths from 1980 to 2010 (http://nadp.sws.uiuc.edu/; accessed Sept. 25, 2015). In response, the number of lakes with acid neutralizing capacity (ANC) less than 0 meq $\mathrm{L}^{-1}$ decreased from 15.5\% in 1991-1994 to 8.3\% in 2006-2007 (Waller et al., 2012). Of 42 randomly selected Adirondack lakes, 35 showed ANC increases during this period and only one lake showed an ANC decrease, which was attributed to increased organic acidity. Similar to recovering lakes in other regions, the increase in ANC was limited because the decrease in $\mathrm{SO}_{4}$ concentrations was partially offset by a decrease in Ca concentrations. In lakes in the Adirondacks and New England from 2000 to 2010 ANC increases continued, but base cation concentrations decreased in the Adirondacks and did not change in New England (Strock et al., 2014).

Despite slow increases in ANC, other chemical changes from decreased acidic deposition are stimulating recovery responses in lakes. Recent evidence has shown that lake inputs of dissolved organic carbon (DOC) and associated $\mathrm{P}$ are increasing, and that concentrations of both are positively correlated with chlorophyll $a$ in numerous Adirondack lakes (Gerson et al., In Press). Furthermore, increases in chlorophyll $a$ were found to be inversely correlated with $\mathrm{NO}_{3}$ concentrations in this study and a previous Adirondack study (Momen et al., 2006), and phytoplankton biomass was found to be inversely correlated with $\mathrm{NO}_{3}$ in Ontario lakes (Findlay, 2003). Net biological assimilation of $\mathrm{NO}_{3}$ represents a biological in-lake neutralization process that has begun to contribute to chemical recovery in lakes. Josephson et al. (2014) also found increases in chlorophyl $a$ and decreases in $\mathrm{NO}_{3}$ in an Adirondack lake where chemical recovery has led to the natural reestablishment of the brook trout population. Since the early stages of acid rain research, it was recognized that in-lake biological processes had the potential to provide acid neutralization in the recovery process (Kelly et al., 1987), and results now indicate that these processes are taking effect. The decrease in atmospheric deposition of $\mathrm{N}$ may also contribute to decreasing concentrations in lakes, but this possibility needs further research. 


\subsection{Streams}

Less data are available on trends in stream chemistry than lake chemistry, but the limited data suggest that chemical recovery in streams may be weaker than in lakes. From 1970 to 2010, stream ANC in the Hubbard Brook Experimental Forest, NH (HB) reference watershed increased from approximately $-30 \mu \mathrm{eq} \mathrm{L} \mathrm{L}^{-1}$ to $+10 \mu \mathrm{eq} \mathrm{L} \mathrm{L}^{-1}$ (Likens and Buso, 2012). Although these data represented a sizable increase in $\mathrm{ANC}$, the rate of change of $1 \mu \mathrm{eq} \mathrm{L}^{-1} \mathrm{y}^{-1}$ was considerably less than the decrease in $\mathrm{SO}_{4}$ of $2.4 \mu \mathrm{eq} \mathrm{L}^{-1}$. A large (46\%) decrease in Ca concentrations over the 40 years had a strong effect in limiting the rate of ANC increase. The decreasing base cation concentrations have resulted in a hysteretic acidification and recovery pattern as depicted in Figure 1. Although continuous records of surface water chemistry do not extend earlier than 1960, the acidification phase shown in Figure 1 was inferred from data on soil Ca changes that dates back to the early 1930s in the northeastern US (Johnson et al., 2008). The future trajectory of chemical recovery is uncertain in low-base systems because extrapolation of the existing trends leads to unrealistically dilute surface water concentrations (Likens and Buso, 2012).

Figure 1. Schematic diagram that summarizes the current literature regarding acidification (red) and recovery (blue) phases of lake and stream chemistry as a function of acidic deposition levels. Future recovery is assumed to approach pre-industrial conditions, although the conditions of full recovery remain uncertain.

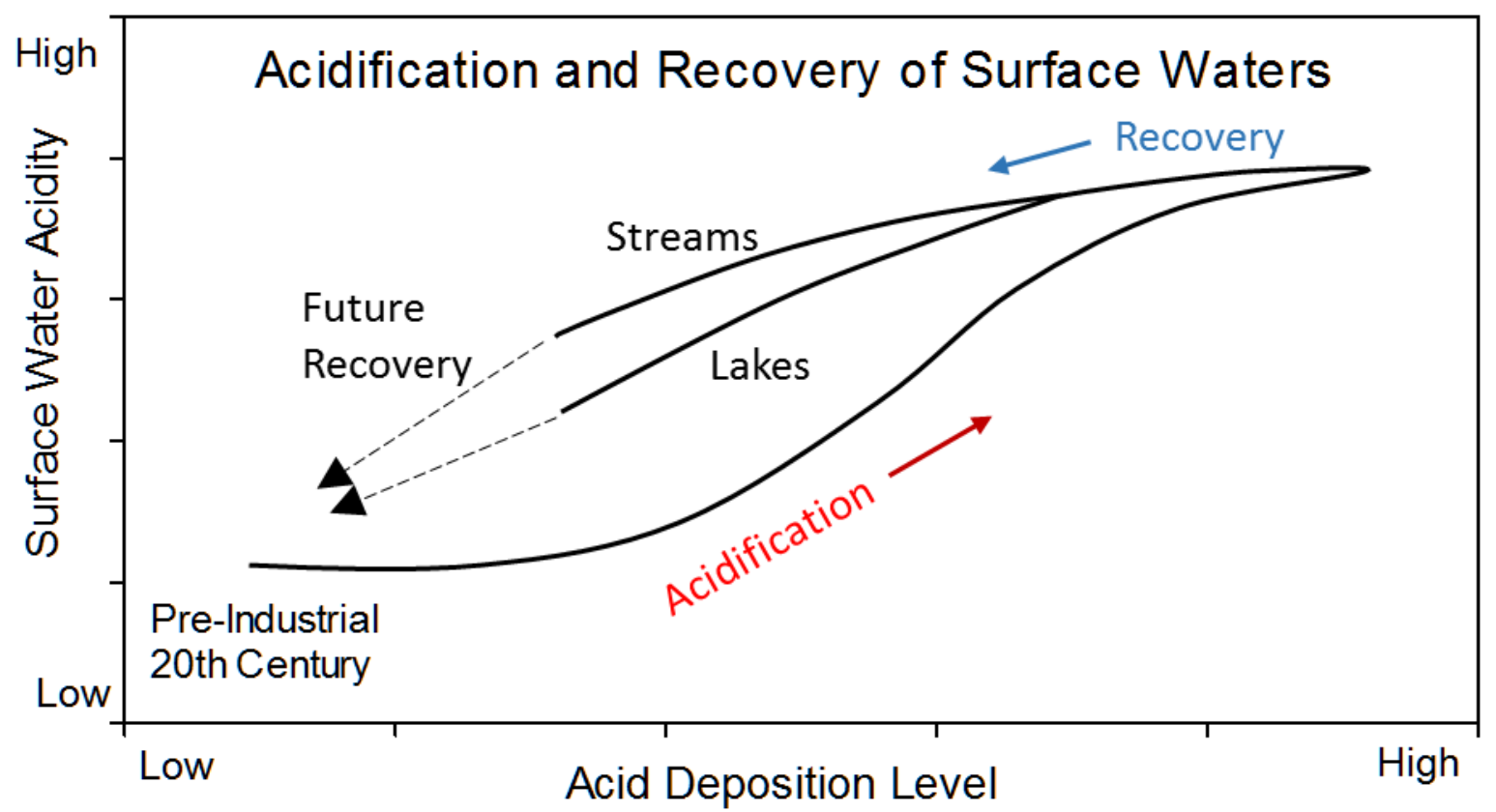

In the Catskill Mountain region, NY, ANC did not change from 1992-2001 in four of five monitored streams, and in the one stream where ANC did increase, the rate was only $0.48 \mu$ eq $\mathrm{L}^{-}$ ${ }^{1} \mathrm{y}^{-1}$ (Burns et al., 2006). Concentrations of base cations decreased in four of five streams, and 
did not change in the fifth. Twelve streams in the Adirondack region sampled multiple times (over varying season and flow) in the early 1980s and again in 2003-2005 showed increases in ANC in four streams and no change in the remainder. Rates of increase were less than $0.7 \mu \mathrm{eq}$

$\mathrm{L}^{-1} \mathrm{y}^{-1}$ except in one beaver-impacted stream (Lawrence et al., 2011). Data from two additional Adirondack streams monitored from 1999-2008 showed small increases in ANC and pH in one stream, and no changes in the other (Lawrence et al., 2011).

Trends data were not available to determine if episodic acidification was lessening, but spatial survey data indicated that increased acidity during elevated flows remains a problem in eastern U.S. streams. A recent analysis of trends in $\mathrm{pH}$ and ANC at Hubbard Brook indicate a similar rate of recovery during snowmelt as observed annually (Fuss and Driscoll, 2015). The spatial extent of episodic acidification was assessed in the western Adirondack region in 20032005, during snowmelt, summer baseflow and fall high-flow periods. Results showed that 718 of $1237 \mathrm{~km}$ of assessed stream reaches, were prone to acidification during high flow to a level at which toxic forms of $\mathrm{Al}$ were mobilized (Lawrence et al., 2008). This study also found that during snowmelt in 2004, 55 of 188 sampled streams (29\%) had an ANC less than $0.0 \mu \mathrm{eq} \mathrm{L}{ }^{-1}$, whereas in August 2004, 29 of the sampled streams (15\%) had an ANC less than $0.0 \mu$ eq L ${ }^{-1}$ (Lawrence et al., 2008). Episodic acidification of streams was also assessed over the entire length of the Appalachian Trail (Maine to Georgia) by sampling 188 streams at base flow and elevated flows in 2010-2012 (Lawrence et al., 2015b). Flow normalization indicated that the median ANC of these streams was 54 meq L ${ }^{-1}$ at low flow and declined to 23 meq L $\mathrm{L}^{-1}$ at high flow, with about $13 \%$ showing ANC $<0$ meq $\mathrm{L}^{-1}$.

\subsection{Soils}

The $\mathrm{Ca}$ decrease observed in surface waters is in part tied to the decreases in atmospheric $\mathrm{S}$ and $\mathrm{N}$ deposition, but the depletion of $\mathrm{Ca}$ in soils from acidic deposition also plays a role (Driscoll et al., 2001). As soil Ca is reduced, the vulnerability of both terrestrial and aquatic ecosystems to acidification increases (Lawrence et al., 1999; Likens et al., 1996; Rice and Herman, 2012). Furthermore, decreases in atmospheric deposition of Ca have occurred over the past several decades, exacerbating the decreasing availability of $\mathrm{Ca}$.

Acidic deposition has been linked to decreases in acid extractable or exchangeable $\mathrm{Ca}$ in soil (Johnson et al., 2008; Warby et al., 2009; Watmough and Dillon, 2004), although a lack of change has also been observed in some resampling studies (Hazlett et al., 2011; Yanai et al., 1999). In the early stages of acidic deposition, release of $\mathrm{Ca}$ increased, providing buffering of surface waters, but continuing loss of $\mathrm{Ca}$ resulted in depletion, which led to release of acidic cations $\left(\mathrm{H}^{+}\right.$and $\left.\mathrm{Al}\right)$ as $\mathrm{Ca}$ concentrations in stream water decreased. This effect was documented in soil resampling over 75 years in western Russia (Lawrence et al., 2005), as well as in experimental watershed acidification studies such as described in (McHale et al., 2007). Most recently, soil resampling in the northeastern U.S. and eastern Canada, found no decreases in exchangeable $\mathrm{Ca}$ in the organic horizon in any of the 18 study sites, and three sites showed increases (Lawrence et al., 2015a). In the upper B horizon, decreases were observed in 4 of 23 sites and no increases were observed (Lawrence et al., 2015a). Despite large decreases in acidic deposition, restoration of available $\mathrm{Ca}$ in the soil has to date not been observed. The relative changes in Ca concentrations in streams and soils estimated from the pre-industrial period to the present are summarized in Figure 2. In neither case do available data indicate concentrations increasing toward pre-industrial levels. 
Figure 2. Schematic diagram summarizing the current literature regarding the effect of $\mathrm{Ca}$ depletion on the relative variations in $\mathrm{Ca}$ concentrations of streams and soils from pre-industrial times to the present.

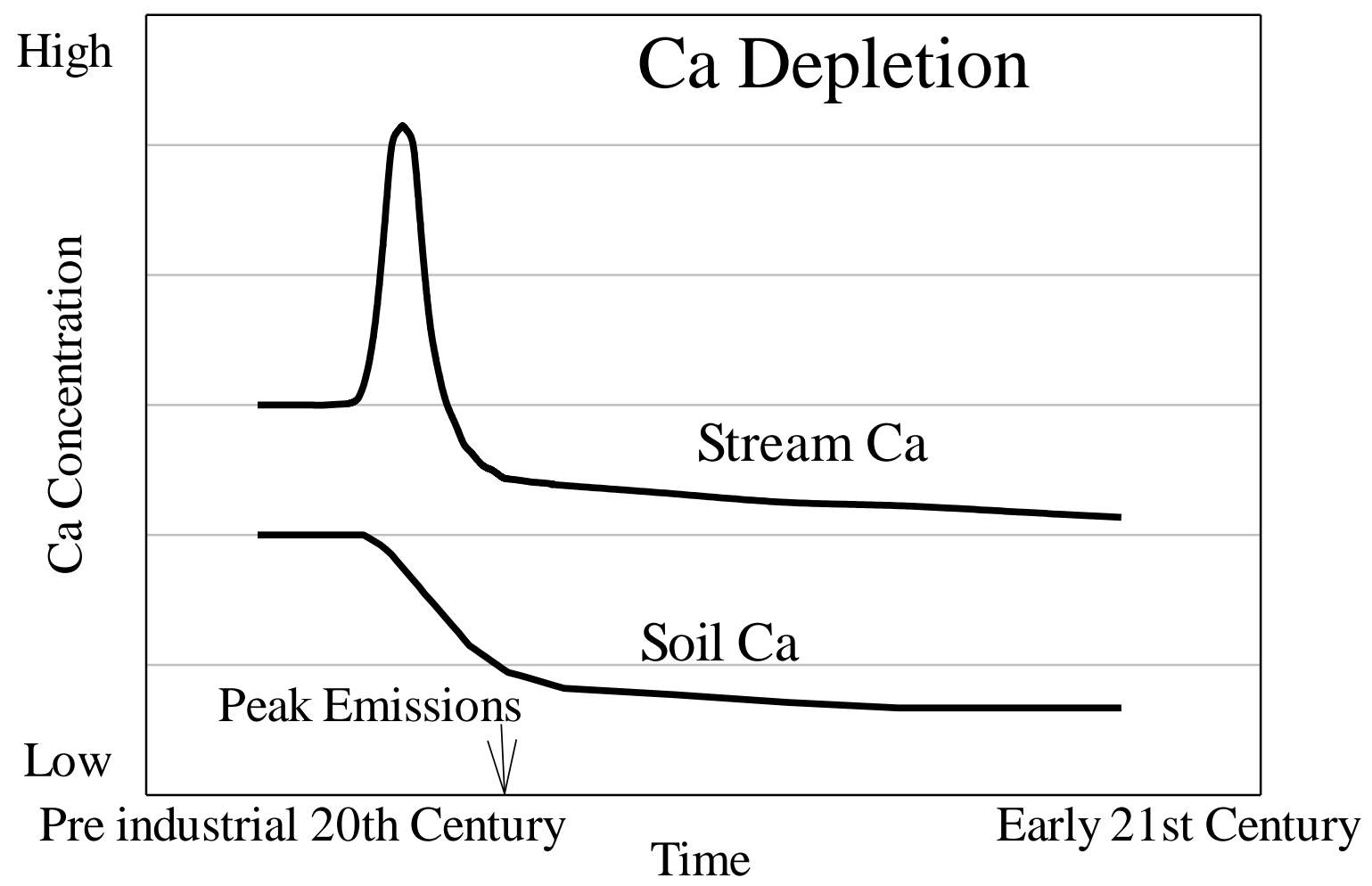

Soil Ca depletion has been linked to multiple negative effects on forest ecosystems, including reduced cold tolerance (Halman et al., 2008; Hawley et al., 2006) and general physiological stress (Minocha and Long, 2004) in red spruce (Picea rubens) trees. Poor seedling survival, low canopy vigor (Sullivan et al., 2013), elevated branch dieback (Schaberg et al., 2006), and reductions in stand health and growth (Duchesne et al., 2002; Long et al., 2009) in sugar maple (Acer saccharum) trees have also been linked to low soil-Ca availability. In the 
understory, soil Ca availability has also been linked to (1) the presence and abundance of vascular plant species (Horsley et al., 2008), (2) snail community richness and abundance (Beier et al., 2012), and (3) salamander species composition (Beier et al., 2012). Furthermore, depletion of $\mathrm{Ca}$ has been linked to adverse effects on forest bird species through reduced availability and nutritional value of food sources (Hames et al., 2002; Pabian and Brittingham, 2007).

Depletion of $\mathrm{Ca}$ in soils has also been linked to effects in aquatic systems by lowering the availability of $\mathrm{Ca}$ as a nutrient. Decreased Ca concentrations in lakes has impaired the growth of key zooplankton species in pelagic food webs (Jeziorski et al., 2012; Jeziorski et al., 2008), and extremely low base cation concentrations have been linked to reduced health of trout populations in water bodies recovering from acidification (Enge and Kroglund, 2011). Benthic algae species composition in Norway rivers was also found to be a useful tool for characterizing concentrations of $\mathrm{Ca}$ in rivers recovering from acidification (Schneider, 2011).

\section{Methods of Liming-Benefits, Limitations and Drawbacks}

\subsection{Direct Lime Application to Lake Surfaces}

Adding lime directly to the surface of lakes provides a seemingly inexpensive and straightforward method for raising $\mathrm{pH}$ and ANC of lakes. This approach was extensively researched in North America and Europe in the 1980s, when acidic deposition rates were typically three to four times the rates in 2010-2015. In two Adirondack lakes limed in May 1985, ANC increased from negative values up to 450-550 meq $\mathrm{L}^{-1}$ within one month. However, by late fall of the same year high flushing rates caused by high precipitation and elevated inflows had removed $65 \%$ of added ANC in one lake and $91 \%$ of added ANC in the second lake (Driscoll et al., 1989). Because of the short hydraulic residence times of these lakes (174 $\mathrm{d}$ and $63 \mathrm{~d}$ ), reacidification was essentially complete in less than 12 months (Driscoll et al., 1989). Neutralization lasted longer in an Ontario lake with a residence time of approximately $1000 \mathrm{~d}$ (Molot et al., 1990a). Liming in 1983 raised the average annual $\mathrm{pH}$ from 4.9 to 6.9, although by 1985, pH depressions down to 5.7 were measured (Molot et al., 1990a), and by 1988 average annual $\mathrm{pH}$ had decreased to 5.7 (Keller et al., 1992).

Further liming research on Adirondack lakes showed that total dissolution efficiency of $\mathrm{CaCO}_{3}$ ranged from $17 \%$ to $59 \%$ (Gloss et al., 1988). Furthermore, this study found that dissolution rates decreased to zero within 3 years after treatment because $40 \%$ to $80 \%$ of the added lime settled in surficial sediments where little or no further dissolution occurred.

Modeling based on data from Swedish lakes showed that deactivation of lime that had settled to the bottom occurred within 0.5 to 3 years and that beyond one year after application, the rate of reacidification was determined mainly by flushing rate (Sverdrup and Warfvinge, 1985).

Direct lake liming to combat the high acidic deposition rates of the 1980s was found to be largely ineffective at producing sustained neutralization of acidity. Because treatment frequency was dependent not only on average lake residence time, but also lake inflows, which varied with weather, knowing when to repeat liming to prevent reacidification required thorough monitoring of water chemistry. For these reasons, direct lake liming was not widely adopted in North America, although an operational program was begun on a group of slow-flushing lakes in the Adirondack region by the State of New York and continues to the present (http://www.dec.ny.gov/pubs/43763.html; accessed June 9, 2015). 
With lake recovery underway and acidic deposition rates decreasing, protection of lakes from further acidification is no longer an issue. The factors that limited the benefits of direct lake liming in the 1980s remain and the contemporary environment of strengthening chemical recovery has added new considerations to the use of direct lake liming. Information on the chemical status of lakes before the onset of acidic deposition becomes important if the target value is the pre-industrial chemistry. In many cases this information is not available and can only be approximated with hindcast models. As ambient recovery proceeds towards the selected target value (often $\mathrm{pH}$ 6.0), excess additions of lime should be avoided and abrupt increases in $\mathrm{pH}$ that accompany the treatment could be detrimental to ongoing recovery. Rapid increases in $\mathrm{pH}$ from liming, have been reported to reduce chlorophyll by $75 \%$ in 10-11 days (Bukaveckas, 1989). Large declines and species shifts of zooplankton communities can also result from rapid pH increases (Schaffner, 1989). Disruption of plankton communities can alter complex food web dynamics. For example, phytoplankton productivity per unit biomass decreased with increased lake $\mathrm{pH}$ in a limed Adirondack lake. This response was linked to lower zooplankton grazing rates triggered by a decline in dominant zooplankton taxa from increased $\mathrm{pH}$ (Bukaveckas, 1993). When liming resulted in more moderate short-term increases in $\mathrm{pH}$, biomass of phytoplankton and zooplankton did not change substantially, although community composition was altered (Molot et al., 1990b).

The role of increasing productivity in lakes as a mechanism to accelerate recovery has, to date, not been studied directly. However, results such as those presented in Josephson et al. (Josephson et al., 2014) and Gerson et al. (Gerson et al., In Press) are consistent with in-lake neutralization processes that were well understood in the 1980s (Kelly et al., 1987). Therefore, short-term ecosystem disruptions from the $\mathrm{pH}$ fluctuations that follow lake liming could set back natural chemical recovery processes. . If decreases in primary productivity occur following liming, acid neutralization from algal assimilation of $\mathrm{NO}_{3}$ and $\mathrm{SO}_{4}$ will become less effective as the plankton community adjusts to the severe short-term changes in chemistry. A stable recovery of the lake ecosystem may be achieved more readily by allowing natural ecosystem adjustments to the lower deposition levels rather than introducing periodic chemical fluctuations. These relationships suggest that as recovery proceeds, the potential risks of direct lake liming could increase relative to the benefits.

\subsection{Direct Liming of Running Waters}

Acidified streams present different liming challenges than lakes. Extremely short residence times over a given reach mean there is essentially no storage of water so neutralization must rely on dissolution in flow regimes that can fluctuate two to three orders of magnitude within a single storm (Likens et al., 1977). Furthermore, stream chemistry is more temporally variable than lake chemistry, and more prone to episodically acidify during high flows. Streams that are considered to be chronically acidic also tend to increase in acidity during high flow episodes, although depressions in $\mathrm{pH}$ and ANC are less in these streams than in streams with higher baseflow buffering (Lawrence et al., 2008). Episodic acidification remains an ongoing ecological problem that hinders biological recovery in streams (Baldigo et al., 2007; Kowalick et al., 2007). The tendency of streams to be more acidic in the upstream direction (Johnson et al., 2000; Lawrence et al., 2008) adds spatial variability that further complicates remediation of acidified streams.

To accomplish neutralization under widely varying flows and chemistry, $\mathrm{pH}$-controlled dosing systems have been used to adjust additions of slurried lime to changing conditions. 
Although adding lime in a slurried form improves the dissolution rate, a fraction of the lime settles to the channel bottom without dissolving as the slurry moves downstream. Dissolution of 60 to 70 percent of slurried lime has been reported in automated dosing applications (Eggleton et al., 1996; Simmons and Cieslewicz, 1996; Zurbuch et al., 1996). Generally the settled lime results in high $\mathrm{pH}$ and high $\mathrm{Ca}$ concentrations in sediment pore waters (Menendez et al., 1996; Simmons and Cieslewicz, 1996), although in one study, no difference in pore water chemistry was observed between reference and limed sites (Eggleton et al., 1996).

Dosing systems have been used extensively in Sweden and Norway (Clair and Hindar, 2005), in some cases for as long as 20 years (Hesthagen et al., 2011). The use of dosers in North America has been much more limited, but acidic episodes have been effectively neutralized during periods of sensitivity for key fish species (Hall et al., 1994). Dosers have also been run for year-round stream treatment and success has been shown at maintaining monthly average $\mathrm{pH}$ and ANC measurements above target values (Menendez et al., 1996; Simmons and Cieslewicz, 1996). However, in the one study that monitored episode chemistry, $\mathrm{pH}$ depressions below 5.5 were recorded throughout the four-year treatment period (Zurbuch et al., 1996). Positive responses in fish survival (Simmons et al., 1996) and reproduction (Menendez et al., 1996) were reported with dosing systems, although Hall et al. (1994) found that additional fisheries management would be needed to restore the fishery. Macroinvertebrates were reported to show little or no response from three to four years of year-round dosing with lime (Eggleton et al., 1996; Simmons and Doyle, 1996).

Dosing systems have the advantage of being automated, but the equipment needs to be monitored with site visits at least several times a week to maintain accurate calibration and correct malfunctions as they occur (Simmons and Cieslewicz, 1996; Zurbuch et al., 1996). To maintain the correct dosages, water chemistry and flow must also be monitored and the length of the stream reach that can be treated by a single dosing station is generally limited to a few kilometers. The rapid decrease of Al solubility that occurs in the mixing zone directly downstream of the doser tends to increase toxicity above that of untreated waters until precipitation of the $\mathrm{Al}$ is complete (Weatherly et al., 1991). This can also happen where acidified tributaries mix with the treated reach, reducing the length of stream reach being effectively treated.

The addition of lime directly to streams in dry particle form provides a much simpler alternative to dosing systems. In this approach, the lime is generally added as a single dose at one location. The lime forms a pile within the channel until it is distributed downstream by the flowing water. The downstream distribution of the lime is dependent on flow conditions and the particle size of the lime. An optimum particle size of $0.76 \mathrm{~mm}$ was identified by Downey et al. (1994) to maximize dissolution but minimize flushing of the lime downstream of the desired treatment reach. A single application of lime with this particle size maintained $\mathrm{pH}$ above 6.0 during all but the highest flow conditions for 400 days in a Virginia stream where $\mathrm{pH}$ ranged between 4.6 and 5.3 immediately upstream of the treatment. However, neutralization decreased through the first year, and the highest flows resulted in $\mathrm{pH}$ depressions below 5.0 (Downey et al., 1994).

In West Virginia, 13.3 tons and 33.3 tons of relatively course limestone gravel $(6.4 \mathrm{~mm}$ diameter) added at single points in neighboring stream reaches of similar drainage area (7.1-7.2 $\mathrm{km}^{2}$ ) and treatment length (approximately $2 \mathrm{~km}$ ) resulted in similar changes in stream chemistry despite the difference in dose (Ivahnenko et al., 1988). Dosage was also found to have a limited effect on the extent of neutralization in Pennsylvania streams, where doubling annual 
applications provided little additional neutralization (Keener and Sharpe, 2005; LeFevre and Sharpe, 2002). This result may have been related to annual flows that were $22 \%$ higher in the years of double doses than in the single-treatment years. Clayton et al. (1998) also found no difference in neutralization between a dose estimated to equal twice the acid load of the stream and a dose estimated to be four times the acid load of that stream.

Results suggest that particle size is more important than dose when using bulk applications. The particle size used in the West Virginia (Ivahnenko et al., 1988) and Pennsylvania (Keener and Sharpe, 2005) studies was about 10 times that used in the Virginia study (Downey et al., 1994), where the treatment was more effective in maintaining $\mathrm{pH}$ above 6.0 and preventing large $\mathrm{pH}$ depressions during high flows. This conclusion was supported by the study of Clayton et al. (1998), which showed more effective neutralization with particles in the size range of $0.063 \mathrm{~mm}$ to $1 \mathrm{~mm}$ than with particles in size ranges from 0.063 to $7 \mathrm{~mm}$ or 1 to $8 \mathrm{~mm}$. (Clayton et al., 1998).

Substantial evidence shows that the addition of lime directly to streams, whether through sophisticated dosing systems or by simply dumping particulate lime into the stream channel, can result in substantially improved water quality of acidified streams in the short term. Stream liming studies have also shown consistent success in improving survival and reproduction of brook trout (Salvelinus fontinalis Mitchell) in the first few years after liming. However, liming to restore reproducing populations of other fish species has been largely unsuccessful (Clayton et al., 1998; Hall et al., 1994; Hudy et al., 2000; Menendez et al., 1996). Restoration of brook trout, a species of relatively high acid tolerance (Driscoll et al., 2001), may not require as high a level of acid-neutralization as other fish species. Most macroinvertebrate assessments indicated either no response (Hudy et al., 2000; Simmons and Doyle, 1996) or negative responses to liming (Clayton and Menendez, 1996) (Keener and Sharpe, 2005). The lack of positive effects on macroinvertebrates was attributed to inconsistent water chemistry in the mixing zone and the coating of natural stream substrates with lime particles (Clayton and Menendez, 1996; Keener and Sharpe, 2005).

Most information on the effects of stream liming is based on data collected within 5 years of treatment. The one study that was able to compare liming effects over varying treatment durations found no trends in recovery among eight West Virginia streams annually limed from 2 to 20 years (McClurg et al., 2007). As in other studies, McClurg et al. (2007) found positive results soon after treatment, particularly for brook trout, but little further recovery as treatments were continued. A lack of full recovery despite continued treatments may be related to fluctuating water chemistry over the length of channel where lime has been deposited on the streambed. The effectiveness of dissolution, acid neutralization, and Al precipitation vary with the rate at which water moves through the reach as well as the rate at which water enters the channel from tributaries and riparian areas. Because streams that could benefit from liming occur in watersheds where soils are base depleted, dissolved Al is sporadically delivered into the stream, which destabilizes the water chemistry as Al polymerizes from the mixing of limed water with untreated water (Poleo et al., 1994). Furthermore, reduced acid neutralization during increased flow was reported in all studies and was also likely to contribute to incomplete ecosystem recovery from liming. Although high-flow episodes were a well-recognized problem in these studies (Downey et al., 1994; Ivahnenko et al., 1988; Zurbuch et al., 1996), water sampling designs in liming studies have rarely been adequate to characterize fully the magnitude and duration of flow-driven chemical variability. Therefore, the effect of episodes in suppressing recovery from liming may not be fully understood. 


\subsection{Liming Hydrologic Source Areas}

The difficulties of using direct liming of lakes and streams to achieve stable $\mathrm{pH}$ levels that are favorable to aquatic biota led to terrestrial liming as a means to treat acidified surface waters. Applying lime to the landscape rather than directly to surface waters was viewed as an improved method to remediate acidified surface waters because the acidity is treated before reaching the aquatic ecosystem (Clair and Hindar, 2005). The lime may be distributed over the entire watershed, or just the hydrologic source areas-locations within the watershed where subsurface flow converges to create surface runoff.

Hydrologic source-areas tend to be either wetlands or riparian areas where soils are saturated through much of the year. Because hydrologic source-areas are closely connected to surface waters, they have a large influence over surface water chemistry. Therefore, these areas can be targeted for liming to reduce the costs of liming the entire watershed (Clair and Hindar, 2005). The liming of hydrologic source-areas is advantageous because saturated soils provide conditions for effective lime dissolution and a direct flow path to surface water, particularly during high flows when episodic acidification occurs. High concentrations of organic matter typical in soils of hydrologic source areas also provide cation exchange capacity that stores $\mathrm{Ca}$ in a form available for acid buffering (Cirmo and Driscoll, 1993). In an acidified watershed in the western Adirondack region of New York, $\mathrm{pH}$ below a limed wetland and beaver pond remained above 6.2 during spring snowmelt, although during high flow episodes $\mathrm{pH}$ decreases were observed (Newton et al., 1996). Bradley and Omerod (2002) reported that long-term liming of hydrologic source-areas did not prevent negative effects of episodic acidification on stream macroinvertebrates, although this study also showed that a single application of lime to a hydrologic source-area provided a degree of neutralization for twelve years (Bradley and Ormerod, 2002).

Liming of hydrologic source-areas has the limitation of treating surface waters without benefiting the terrestrial ecosystem and has been found to damage the vegetation of naturally acidic wetland ecosystems (Hindar et al., 1996; Traaen et al., 1997). The organic-rich soils of naturally acidic hydrologic source-areas also provide high base-neutralizing capacity, which consumes a large amount of ANC contributed by the dissolving lime. Large doses of lime are therefore needed to overcome the high base consumption of the peat so that $\mathrm{pH}$ of the water leaving the source area is sufficiently raised (Hindar et al., 1996). Little or no effect on microbial respiration or the chemistry of peat or pore waters was observed from a moderate dose of lime (0.4 - $4 \mathrm{Mg} \mathrm{Ca} \mathrm{ha}^{-1}$ ) applied to an Adirondack wetland (Yavitt and Fahey, 1996). Because storage of water in wetlands varies with precipitation regime and season, the effectiveness of wetland liming can also vary as discharge and recharge of source areas occur over the year (Yavitt and Fahey, 1996).

\subsection{Liming Forest Soils}

Terrestrial liming has also been done for the purpose of remediating Ca-depleted soils to aid ecosystem recovery throughout a watershed or in specific forest or stand types. Terrestrial liming is usually done by aerial application with helicopters, as is widely done in commercial forests in Germany (Permalink http://dw.com/p/1AKi7; published Nov. 19, 2013), or with spreaders pulled by tractors or skidders where terrain and stand density are suitable for landbased equipment, such as demonstrated in Long et al. (1997). 
A recent meta-analysis of studies that added $\mathrm{Ca}$ by either liming or wood-ash showed that $75 \%$ of the trials increased base saturation, $67 \%$ increased soil $\mathrm{pH}$, and $33 \%$ increased tree growth. These results provided a clear indication that liming was not warranted at some sites, although limited information was provided to determine the type of sites most likely to benefit (Reid and Watmough, 2013). Increasing Ca availability for tree species with relatively high Ca demand is one potential benefit of liming. Sugar maple (Acer saccharum) in particular has been a focus of liming studies because of its high commercial value, its prevalence in soils that have experienced $\mathrm{Ca}$ depletion from acidic deposition, and its widespread decline that has been linked to soil-Ca depletion (Duchesne et al., 2002; Hallet et al., 2006; Sullivan et al., 2013). Liming of hardwood forests in Pennsylvania where sugar maple trees were experiencing severe decline episodes increased basal area growth and reduced mortality of sugar maple, whereas basal area growth and mortality in American beech (Fagus grandifolia) were not affected and black cherry (Prunus serotina) experienced decreased basal area growth and increased mortality (Long et al., 2011). In this study, 22.4 $\mathrm{Mg} \mathrm{ha}^{-1}$ of dolomitic limestone was applied in 1985. By 2001 only 3 $\mathrm{kg} \mathrm{ha}^{-1}$ of the lime remained undissolved, although exchangeable Ca concentrations in soil to depths of $45 \mathrm{~cm}$ were significantly higher than untreated soils up to 2006 (Long et al., 2015).

Similar effects of liming on sugar maple have been reported in Quebec at doses as low as $5 \mathrm{Mg} \mathrm{ha}^{-1}$ (Moore et al., 2012). In a recent review of liming studies that focused on sugar maple, Moore et al. (2015) concluded that liming was warranted as a restoration or management tool to maintain sugar maple growing in base-poor soils. Although liming has resulted in consistent growth increases of sugar maple in base-poor soils, Nolet et al. (2015) found that liming alone did not favor regeneration and growth of sugar maple over American beech, with which it often coexists in acidic, low-Ca soils (Duchesne et al., 2005). Further studies of liming effects on stand dynamics are needed.

Effects of liming on components of forest ecosystems other than trees have also been evaluated. This includes effects on soil organic matter, which have shown variable results. Nineteen years after lime application $\left(2.8 \mathrm{Mg} \mathrm{Ca} \mathrm{ha}^{-1}\right.$ ) in an Adirondack watershed, $\mathrm{pH}$ and exchangeable $\mathrm{Ca}$ of the forest floor remained elevated relative to unlimed soils, and the total carbon content of the forest floor of limed soils was more than twice that of unlimed soils (Melvin et al., 2013). A recent, short-term liming experiment in the Adirondack region also found that liming at a rate of $3.7 \mathrm{Mg} \mathrm{Ca} \mathrm{ha}^{-1}$ decreased rates of hardwood litter decay, possibly by reducing arthropod populations. However, leaf litter with high Ca concentrations decomposed more quickly than leaf litter with lower Ca concentrations (McCay et al., 2013). Decreases in forest floor carbon pools from liming have also been observed (Kreutzer, 1995.; Persson et al., 1995). Reasons for the variable responses of forest floors to liming could include changes in faunal community composition (Auclerc et al., 2012; McCay et al., 2013), $\mathrm{CO}_{2}$ efflux (Melvin et al., 2013), and effects on complex C-N interactions (Melvin et al., 2013). Most investigations of the processes thought to control liming effects on organic matter are based on short-term incubations. More long-term studies of these processes are needed to better understand the effects of liming on forest floor carbon dynamics.

One clear risk of liming is the potential to create conditions favorable to non-native invasive earthworm species (Moore et al., 2015; Watmough and Meadows, 2014). Invasive earthworms actively incorporate forest floor litter downward into the mineral soil, which results in the loss of some or all of the forest floor (Holdsworth et al., 2008). The effects of these changes on nutrient availability and forest growth are not fully understood. Nevertheless, most invasive earthworm species are acid-intolerant and are not found in acidic forest soils (Moore et 
al., 2013). Liming was found to increase survival and reproduction of two non-native earthworm species in base-poor Canadian soils where they were currently not found. In addition to reducing forest floor mass, invasive earthworms have been shown to substantially decrease organic $\mathrm{C}$ and $\mathrm{N}$ concentrations and increase $\mathrm{C}$ to $\mathrm{N}$ ratios in this horizon (Moore et al., 2013; Watmough and Meadows, 2014) Increased cycling of organic carbon in the forest floor has large implications for forest nutrient availability, but further study is needed to fully assess ecosystem impacts.

Little research has been done on the effects of liming on terrestrial vertebrates, but Pabian and Brittingham (2007) found that liming of acidified forest soils increased abundance of songbirds and snails, although no significant effects were seen in territory size and eggshell thickness. The short-term effects of liming on the red-backed salamander (Plethodon cinereus) were evaluated in a microcosm experiment (Moore, 2014). This species, a top predator in the soil-detritus food web and highly abundant in regions affected by acidic deposition, is found in a wide range of soil $\mathrm{pH}$ conditions. Liming, including direct contact with finely-ground lime, did not result in negative effects during the experiment.

\subsection{Wollastonite Addition at the Hubbard Brook Experimental Forest}

Limestone of various mineral compositions has generally been used to neutralize soil acidity in terrestrial applications because it weathers more rapidly than other Ca-bearing minerals. However, in 1999, wollastonite, a silicate mineral with high Ca content, was applied to a watershed in the Hubbard Brook Experimental Forest, NH, where Ca depletion from acidic deposition was well documented (Likens and Buso, 2012). The purpose for using wollastonite was to restore $\mathrm{Ca}$ availability at a more moderate rate than limestone so that $\mathrm{Ca}$ release occurred over a longer period. The weathering rate obtained by using wollastonite was considered to be more similar to the natural silicate minerals of this watershed than limestone. The treatment goal was to eventually reach estimated pre-industrial levels of soil base saturation (Johnson et al., 2014). By adding wollastonite, the system was not affected by addition of inorganic $\mathrm{C}$ and associated alkalinity, which occurs with limestone treatments. We provide a detailed discussion of the watershed and ecosystem monitoring in this study because it has extended over a decade, providing the most long-term information on how a Ca-depleted system responds to $\mathrm{Ca}$ replenishment (Table 1).

Table 1 - Summary of ecosystem effects of wollastonite addition to a watershed at the Hubbard Brook Experimental Forest, NH.

\begin{tabular}{|l|l|l|}
\hline Compartment & Conclusion & Reference \\
\hline Soil Oa horizon & Exchangeable Ca increased & Cho et al., 2010 \\
\hline Soil Oa horizon & Exchangeable Al decreased & Johnson et al., 2014 \\
\hline Soil water & $\begin{array}{l}\text { Ca, Si, pH, and ANC } \\
\text { increased, inorganic } \\
\text { monomeric Al decreased }\end{array}$ & Cho et al, 2010 \\
\hline Stream water & $\begin{array}{l}\text { Ca export 2\% of application } \\
\text { (nine yrs after treatment) }\end{array}$ & Nezat et al., 2010 \\
\hline Stream water & $\begin{array}{l}\text { Small neutralization during } \\
\text { baseflow and stormflow (4 } \\
\text { yrs. after treatment) }\end{array}$ & (Cho et al., 2009) \\
\hline
\end{tabular}




\begin{tabular}{|l|l|l|}
\hline Soil & N-mineralization decreased & Groffman et al., 2006 \\
\hline Leaves, soil water and stream & $\begin{array}{l}\text { N concentrations did not } \\
\text { change }\end{array}$ & Groffman et al., 2006 \\
\hline Litter & $\begin{array}{l}\text { Decomposition rate of sugar } \\
\text { maple and beech increased }\end{array}$ & Lovett et al., 2015 \\
\hline Trees & $\begin{array}{l}\text { Sugar maple health, } \\
\text { survivorship, and seed density } \\
\text { improved }\end{array}$ & Juice et al., 2006 \\
\hline Tree roots & $\begin{array}{l}\text { Sugar maple fine root Ca } \\
\text { increased and Mn decreased }\end{array}$ & Juice et al., 2006 \\
\hline Tree roots & $\begin{array}{l}\text { Greater mycorrhizal } \\
\text { colonization of sugar maple } \\
\text { roots }\end{array}$ & Juice et al., 2006 \\
\hline Trees & $\begin{array}{l}\text { Increased stress tolerance of } \\
\text { red spruce during cold season }\end{array}$ & Schaberg et al., 2011 \\
\hline Trees & $\begin{array}{l}\text { Biomass and leaf area index } \\
\text { increased }\end{array}$ & Battles et al., 2014 \\
\hline
\end{tabular}

In the Oa horizon, exchangeable Ca concentrations were elevated relative to pretreatment concentrations 3, 7 and 11 years after treatment, and exchangeable $\mathrm{Al}$ concentrations were lower than pretreatment concentrations 7 and 11 years after treatment (Johnson et al., 2014). In the upper $10 \mathrm{~cm}$ of the mineral soil, exchangeable Ca concentrations were elevated relative to pretreatment concentrations 7 and 11 years after treatment, but exchangeable Al concentrations did not differ from pretreatment concentrations 3, 7 or 11 years after treatment. Total concentrations of $\mathrm{Ca}$ in the Oi plus Oe horizons were at a maximum one year after treatment then steadily decreased up to 11 years after treatment, whereas total Ca peaked in the Oa horizon 3 years after treatment and peaked in the upper mineral soil 7 years after treatment (Johnson et al., 2014). In this experiment $19,000 \mathrm{~kg}$ of Ca were applied to the watershed, of which only $360 \mathrm{~kg}$ were exported in stream water over the first 9 years after treatment. Of the approximately $37 \mathrm{~kg}$ of Ca per year being exported from the watershed, isotope ratios showed that only $11 \mathrm{~kg}$ were from wollastonite weathering (Nezat et al., 2010). At the Ca loss rate observed over years 6 to 9 , the wollastonite treatment was estimated to last 1000 years before being fully exported from the watershed.

Soil solution chemistry showed clear treatment effects in years one through three in both organic and mineral horizons despite slower weathering of the Ca-silicate mineral than would have occurred if $\mathrm{Ca}$ was added as limestone (Cho et al., 2010). Concentrations of $\mathrm{Ca}$ in the organic and mineral horizons in the third year were approximately twice those in the year preceding treatment, which resulted in partial acid neutralization of soil solutions. Values of $\mathrm{pH}$ increased from 4.43 to 4.72 and 4.58 to 4.74 in organic and mineral horizons, respectively, and ANC increased from -52.9 to 45.8 and -40.8 to -3.57 meq $\mathrm{L}^{-1}$, respectively, in these same horizons. Neutralization was not sufficient to prevent mobilization of inorganic monomeric Al, although concentrations decreased from 17 to 9.04 and 16.3 to $12.8 \mathrm{mmol} \mathrm{L}^{-1}$ in organic and mineral horizons, respectively. Treatment effects on soil solutions of the upper soil profile were not reflected in stream water three years after treatment. Neutralization of stream water in the treated watershed was minimal relative to the chemistry of the reference watershed, both during baseflow and stormflow (Cho et al., 2010). Both baseflow and stormflow values of ANC in the 
two streams differed by less than 2 meq $\mathrm{L}^{-1}$, although Ca concentrations in the stream of the treated watershed were nearly double that of the reference stream. Concentrations of stream water $\mathrm{Ca}$ in the treated watershed remained stable from year 3 through year 9 (Nezat et al., 2010)

The wollastonite treatment was hypothesized to increase $\mathrm{N}$ mineralization by creating a more favorable $\mathrm{pH}$ for microbial activity. However, in the first four years after treatment, potential net and gross mineralization rates and $\mathrm{N}$ content of microbial biomass decreased in the Oi/Oe horizon, and $\mathrm{N}$ concentrations in streams, soil solutions and foliage showed no responses (Groffman et al., 2006). Although $\mathrm{N}$ cycling was not stimulated by the treatment, decomposition of beech and sugar maple litter was stimulated (Lovett et al., 2015). This response was due to treatment effects on the soil environment rather than an effect of higher $\mathrm{Ca}$ concentrations of the litter itself. In showing an increase in decomposition from $\mathrm{Ca}$ addition but no effect of litter $\mathrm{Ca}$ concentration, the results of Lovett et al., (2015) were opposite of those found by McCay et al. (2013). The difference in results suggests the possibility that moderate additions of $\mathrm{Ca}$ can benefit microbial processes in low-Ca soils, whereas the high dose of Ca used in the McCay study, which was four times that of the Lovett et al. (2015) study, may have chemically stabilized organic matter to some degree (Oste et al., 2002). The result of increased decomposition rates in litter with elevated Ca concentrations shown in the McCay et al. (2013) experiment was also seen in the first year of the Lovett et al. (2015) experiment, but was not apparent by the second year.

As generally observed in liming experiments, application of wollastonite had largely positive effects on forest tree species. Six years after treatment, crown condition of sugar maple was healthier and seed density and survivorship was higher in the treated watershed than in the reference watershed (Juice et al., 2006). Treatment also resulted in higher Ca concentrations and lower Mn concentrations in fine roots and greater mycorrhizal colonization of seedling roots. Red spruce, a species with demonstrated vulnerability to winter injury in low-Ca soils, showed increased stress tolerance during the cold season in the wollastonite-treated watershed (Schaberg et al., 2011). This finding was supported by a severe region-wide winter injury episode in 2003 in which needle loss of red spruce in the reference watershed was approximately three times higher than in the treated watershed, where foliage Ca concentration was significantly higher (Schaberg et al., 2011). Further indication of positive tree responses from the wollastonite addition was seen in aboveground tree biomass, which had remained relatively unchanged since 1980, indicating zero net growth. However by 2006-2007, aboveground tree biomass in the treated watershed was significantly higher than the reference watershed, and this relationship was observed again in 2011-2012 (Battles et al., 2014). Leaf area index was also higher in the treated watershed than the reference watershed from 2006 up to the latest measurements in 2011.

\section{Liming Effects on Mercury Cycling}

Environmental mercury $(\mathrm{Hg})$ contamination is a widespread problem in the US and globally (Driscoll et al., 2013). While Hg contamination can be highly localized due to activities such as mining and waste incineration, atmospheric $\mathrm{Hg}$ that originates from emissions associated with coal combustion, volcanic activity, and other sources is largely responsible for $\mathrm{Hg}$ deposition in locations far removed from most human activities (Pirrone et al., 2010). These locations include many of the same regions such as the Adirondacks and Scandinavia that are also sensitive to acidification (Åkerblom et al., 2014; Evers et al., 2007). Hg contamination is 
manifested through the bioaccumulation of methyl $\mathrm{Hg}$ in aquatic and terrestrial food webs (Driscoll et al., 2013).

The $\mathrm{Hg}$ cycle in terrestrial and aquatic ecosystems is sensitive to $\mathrm{pH}$ and is strongly linked with acidic deposition and ecosystem acidification through biogeochemical processes that affect the cycling of sulfur and carbon (Munthe et al., 2007). Observers have long noted an inverse relation between methyl $\mathrm{Hg}$ and $\mathrm{pH}$ in surface waters and aquatic biota therein (Bloom et al., 1991; Gilmour and Henry, 1991). The dominant mechanism that causes this inverse relation has remained elusive and several potential factors have been invoked that include $\mathrm{pH}$-related effects on productivity, bioconcentration at the base of the food web, rates of bacterial methylation, and biogeochemical processes such as sorption in soils that control $\mathrm{Hg}$ mobility in the environment (Dittman and Driscoll, 2009; Gabriel and Williamson, 2004; Gilmour and Henry, 1991). The abundance of low $\mathrm{pH}$ surface waters in the Adirondacks is believed to contribute to the generally high levels of $\mathrm{Hg}$ found in aquatic biota in the region (Dittman and Driscoll, 2009; Driscoll et al., 1994). In addition to the direct effects of acidity on $\mathrm{Hg}$ cycling, decreasing $\mathrm{SO}_{4}$ concentrations that are a principal driver of $\mathrm{pH}$ recovery in surface waters may decrease the availability of methyl $\mathrm{Hg}$ (Coleman Wasik et al., 2012). This effect results from the dominant role of $\mathrm{SO}_{4}$ - reducing bacteria as $\mathrm{Hg}$ methylators in most environmental settings, which is especially evident in watersheds with an abundance of anoxic environments. Some additional factors could act in opposition to those of increasing $\mathrm{pH}$ and decreasing $\mathrm{SO}_{4}$. $\mathrm{DOC}$ concentrations generally increase as $\mathrm{pH}$ and $\mathrm{ANC}$ increase in surface waters that are recovering from acidic deposition (Evans et al., 2012). Because DOC is strongly associated with $\mathrm{Hg}$ transport in waters, an increase in methyl $\mathrm{Hg}$ concentrations may result from increased DOC concentrations alone (Hongve et al., 2012). Finally, the effects of liming on food webs could influence methyl $\mathrm{Hg}$ bioaccumulation in ways that would vary with environmental settings (e.g., streams, lakes, terrestrial settings).

Several investigators have observed that $\mathrm{Hg}$ levels in fish in limed lakes are lower than those measured in unlimed lakes (Andersson et al., 1995; Håkanson et al., 1988; Sloan and Schofield, 1983). Liming investigations have identified decreased microbial activity (Parkman and Munthe, 1998) and decreased bioavailability (Rask et al., 2007) as likely factors that favor lower methyl $\mathrm{Hg}$ concentrations in surface water and aquatic biota in limed watersheds. The relationship between $\mathrm{pH}$ and methyl $\mathrm{Hg}$ are well enough established to suggest that $\mathrm{pH}$ control through liming could be used as a strategy for mitigating $\mathrm{Hg}$ bioaccumulation in surface waters (Shastri and Diwekar, 2008). However, a strong inverse relation between $\mathrm{pH}$ and methyl $\mathrm{Hg}$ in surface water and biota is not observed in all regional settings (Jardine et al., 2013), suggesting that a complex array of factors including climate variation, DOC concentrations, $\mathrm{SO}_{4}$ availability, feeding habits of various biota, and food web dynamics will determine the extent to which $\mathrm{pH}$ influences the $\mathrm{Hg}$ cycle in a given environmental setting. These observations indicate a need for additional studies that examine the effects of liming on an array of biogeochemical and ecological processes that may affect the $\mathrm{Hg}$ cycle (Figure 3 ). 
Figure 3. Effects of acid deposition and liming on $\mathrm{Hg}$ cycling rates with up or down arrows to indicate how resulting changes in key environmental variables may affect $\mathrm{Hg}$ concentrations.

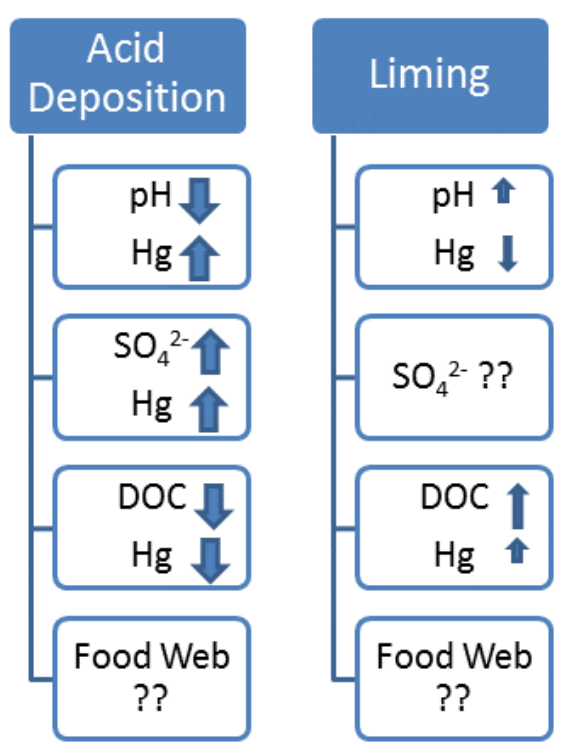

\section{5. $\quad$ Conclusions}

As more is learned about how ecosystems are recovering from acidic deposition it has become clear that recovery rates vary with watershed characteristics and among ecosystem components. Drainage lakes in watersheds with thin glacial till, which are generally considered the most acid-sensitive, are showing stronger recovery responses than lakes in watersheds that are better buffered with relatively thick till deposits (Driscoll et al., 2007). Streams with the lowest ANC have also been found to show the strongest chemical recovery (Lawrence et al., 2011). However, lakes appear to be recovering faster than streams, presumably due to factors such as increased P loading (Gerson et al., In Press). Results of the Adirondack Long Term Monitoring (ALTM) Program showed that 26 of 48 lakes had significant increases in ANC between 1997 and 2007 and only one lake showed a decrease, whereas only 3 of 11 Adirondack streams, largely in the same region, showed increases in ANC attributable to acidic deposition decreases (Lawrence et al., 2011). In Honnedaga Lake, in the southwestern Adirondack region, chemical recovery has led to a substantial increase in the brook trout population, but 18 of 23 tributary streams remain chronically or episodically acidic, with concentrations of inorganic $\mathrm{Al}$ that exceed levels toxic to brook trout (Josephson et al., 2014).

Delays in recovery of surface waters have been widely attributed to depletion of soil Ca (Jeziorski et al., 2008; Likens and Buso, 2012; Warby et al., 2005), and only recently have soil monitoring results shown indications of recovery from acidic deposition (Lawrence et al., 2015a; Lawrence et al., 2012). Although these results show clear indications that mobilization of toxic $\mathrm{Al}$ in the soil has decreased and that further depletion of soil $\mathrm{Ca}$ has largely ceased, evidence of Ca replenishment is not yet apparent.

Within the context of ongoing lake recovery, sluggish stream recovery, and Ca-depleted ecosystems, the addition of $\mathrm{Ca}$ through liming offers a possible method to accelerate recovery. 
Recovery is often viewed as returning the system back to conditions before the onset of acidic deposition. However, it was acidic deposition that initiated much of the collection of environmental data needed to assess effects. Therefore, information on the conditions prior to acidic deposition is extremely limited making the setting of recovery targets difficult. Furthermore, geochemical and biological changes from acidic deposition that have occurred over a few decades may require longer time periods to achieve conditions similar to those before acidic deposition. With these factors and the influences of ongoing climate and landuse changes, restoration to original conditions may not be achievable. Nevertheless, the ecosystems affected by acidic deposition remain highly valued so historical information should be used where possible to serve as a guide to remediate acidic deposition effects that are viewed as negative Higgs et al. (2014). In specific circumstances, liming could be used to achieve this goal, with the recognition that outcomes are likely to differ from original conditions.

Lime could be used to increase $\mathrm{Ca}$ availability to reduce or prevent the mobilization of toxic Al forms in soils, which would help restore both terrestrial and aquatic ecosystems. Current levels of acidic deposition are still sufficiently high to cause elevated concentrations of toxic $\mathrm{Al}$ in surface waters draining soils that are severely $\mathrm{Ca}$ depleted (Lawrence et al., 2013). Increasing $\mathrm{Ca}$ availability through liming could also increase abundance and growth of preferred species of historic significance such as brook trout and sugar maple trees. Furthermore, by increasing $\mathrm{Ca}$ availability of a particular watershed within a Ca-depleted landscape, the range of habitat opportunities is increased, which could potentially promote biodiversity.

Liming could also be used to balance ecosystem nutrient relationships. The ability of vegetation to maintain tight cycling of $\mathrm{N}$, thereby limiting nitrification and associated acidification, has been linked to the availability of $\mathrm{Ca}$, making forest ecosystems depleted of $\mathrm{Ca}$ more likely to exhibit the symptoms of nitrogen saturation (Groffman and Fisk, 2011). Liming could also potentially accelerate the re-establishment of biogeochemical linkages between terrestrial and aquatic ecosystems, such as mineral cation leaching to provide essential nutrients to aquatic systems where decreases in Ca concentrations are ongoing. Liming could, as well, strengthen resistance to environmental stresses, as demonstrated by increased protection of red spruce from winter injury.

Because acid deposition effects are not worsening in North America, liming is no longer needed to prevent damage, but rather to accelerate recovery in a manner that will increase $\mathrm{Ca}$ availability and lead to more stable biogeochemical conditions. The method in which lime is applied is critical in working toward this goal. Adding lime directly to lakes does little to remediate streams or forests and causes chemical and ecological instability from short-term $\mathrm{pH}$ increases to levels that are unrealistic relative to pre-acid rain conditions. Although lakes with harmful levels of inorganic $\mathrm{Al}$ remain, steady decreases in concentrations are occurring (Lawrence et al., 2013) and in-lake biological processes are now contributing to the chemical recovery. As in lakes, stream liming also causes chemical instability although liming sections of acidified streams connected to water bodies with adequate chemistry can be useful if the streams provide habitat needed for certain life stages of fish. However, this does not promote ecosystem recovery and requires repeated treatment.

Treatment of the source of toxic Al by liming the watershed provides an alternative to adding lime directly to the water. Mobilization of toxic Al in the soil occurs at a threshold determined by (1) Ca availability and (2) acidic deposition levels (Lawrence et al., 2007). Adding lime to increase $\mathrm{Ca}$ availability above this threshold would prevent $\mathrm{Al}$ mobilization, thereby benefiting both terrestrial and aquatic ecosystems. Further reductions in acidic 
deposition levels would also be beneficial by reducing the amount of lime needed to prevent $\mathrm{Al}$ mobilization.

The goal of watershed liming should be to increase Ca availability to prevent $\mathrm{Al}$ mobilization and improve nutrient balances, rather than neutralize soil acidity, although this will happen to some degree, depending on dose. Forest ecosystems produce organic acidity through natural processes, which often results in acidic soils. Complete neutralization of natural soil acidity would require large doses of lime and would be destabilizing to the forest ecosystem. Careful selection of dosage is needed to maximize the beneficial effects of liming without causing undesired changes. Wetlands that serve as hydrologic source-areas are often much more acidic than forest soils, with plant communities adapted to that chemical environment. Therefore, liming these areas could be highly disruptive. Additionally, liming wetlands could increase the production of methyl $\mathrm{Hg}$ by increasing the solubility of organic matter. For these reasons, liming of wetlands should be avoided to prevent ecosystem damage therein.

The breadth of information available on liming ecosystems affected by acidic deposition suggests that watershed liming remains a potential option for remediating acidic deposition effects that are viewed as negative. However, more studies are needed to monitor the effects of watershed liming over time intervals sufficient to achieve responses of soils and overstory vegetation. Some of the benefits discussed in this paper may be relatively short-lived, and others not identified because monitoring was not done for the necessary length of time. The ten-plus years of monitoring done in the Hubbard Brook wollastonite experiment demonstrates a sustained recovery effect, but there is little long-term information on the use of lime or other types of Ca-bearing materials to compare with the wollastonite treatment. A number of basic questions relevant to the current context of recovery have not yet been addressed, including (1) what is the optimal dose of lime that should be applied, (2) how long will the application be effective, (3) can watershed liming address both terrestrial and aquatic ecosystems sufficiently, and (4) what are the negative effects with regard to potential $\mathrm{Hg}$ mobilization? Further research is needed to address fully these questions, and the effective use of lime to accelerate recovery will require clearly defined remediation goals that are based on a full knowledge of the acidification/recovery status of the system of interest.

\section{Acknowledgements}

Funding for this review was provided by the New York State Energy Research and Development Authority (NYSERDA) and the U.S. Geological Survey. We thank Howard Simonin for his helpful review.

\section{References}

Åkerblom S., Bignert A., Meili M., Sonesten L., Sundbom M., 2014. Half a century of changing mercury levels in Swedish freshwater fish. Ambio 43, 91-103.

Andersson P., Borg H., Kärrhage P., 1995. Mercury in fish muscle in acidified and limed lakes. Water Air Soil Pollut. 80, 889-892.

Auclerc A., Nahmani J., Aran D., Baldy V., Callot H., Spelda J., Rossi J.-P., Guerold F., 2012. Changes in soil macroinvertebrate communities following liming of acidified forested catchments in the Vosges Mountains (North-eastern France). Ecol. Eng. 42, 260-269. 
Baldigo B.P., Lawrence G.B., Simonin H.A., 2007. Persistent mortality of brook trout in episodically acidified streams of the southwestern Adirondack Mountains, New York. Trans. Am. Fish. Soc. 136, 121-134.

Battles J.J., Fahey T.J., Driscoll C.T., Blum J.D., Johnson A., 2014. Restoring soil calcium reverses forest decline. Environ. Sci. Technol. 1, 15-19.

Beier C.M., Woods A.M., Hotopp K.P., Gibbs J.P., Mitchel M.J., Dovciak M., Leopold D.J., Lawrence G.B., Page B.P., 2012. Changes in faunal and vegetation communities along a soil calcium gradient in northern hardwood forests. Can. J. For. Res. 42, 1141-1152.

Bloom N.S., Watras C.J., Hurley J.P., 1991. Impact of acidification on the methylmercury cycle of remote seepage lakes. Water Air Soil Pollut. 56, 477-491.

Bradley D.C., Ormerod S.J., 2002. Long-term effects of catchment liming on invertebrates in upland streams. Freshwat. Biol. 47, 161-171.

Bukaveckas P.A., 1989. Effects of base addition on primary production in acidified Adirondack (New York) lakes: changes in phytoplankton biomas, productivity, and species composition. Can. J. Fish. Aquat. Sci. 46, 353-360.

Bukaveckas P.A., 1993. Changes in primary productivity associated with liming and reacidification of an Adirondack Lake. Environ. Pollut. 79, 127-133.

Burns D.A., Lynch J.A., Cosby B.J., 2011. Fenn M.E., Baron J.S. National Acid Precipitation Assessment Program Report to Congress 2011: An Integrated Assessment, National Science and Technology Council, Washington, DC, $114 \mathrm{p}$.

Burns D.A., McHale M.R., Driscoll C.T., Roy K.M., 2006. Response of surface water chemistry to reduced levels of acid precipitation: comparison of trends in two regions of New York. Hydrol. Process. 20, 1611-1627.

Cho Y., Driscoll C.T., Blum J.D., 2009. The effects of a whole-watershed calcium addition on the chemistry of stream storm events at the Hubbard Brook Experimental Forest in NH, USA. Sci. Total Environ. 407, 5392-5401.

Cho Y., Driscoll C.T., Johnson C.E., Siccama T., 2010. Chemical changes in soil and soil solution after calcium silicate addition to a northern hardwood forest. Biogeochemistry 100, 3-30.

Cirmo C.P., Driscoll C.T., 1993. Beaver pond biogeochemistry: acid neutralizing capacity generation in a headwater wetland. Wetlands 13, 277-292.

Clair T.A., Dennis I.F., Vet R., 2011. Water chemistry and dissolved organic carbon trends in lakes from Canada's Atlantic Provinces: no recovery from acidification measured after 25 years of lake monitoring. Can. J. Fish. Aquat. Sci. 68, 663-674.

Clair T.A., Hindar A., 2005. Liming for the mitigation of acid rain effects in freshwaters: A review of recent results. Environ. Rev. 13, 91-128.

Clayton J.L., Dannaway E.S., Menendez R., Rauch H.W., Renton J.J., Sherlock S.M., Zurbuch P.E., 1998. Application of limestone to restore fish communities in acidified streams. N. Am. J. Fish. Manage. 18, 347-360.

Clayton J.L., Menendez R., 1996. Macroinvertebrate responses to mitigative liming of Dogway Fork, West Virginia. Restor. Ecol. 4, 234-246.

Coleman Wasik J.K., Mitchell C.P., Engstrom D.R., Swain E.B., Monson B.A., Balogh S.J., Jeremiason J.D., Branfireun B.A., Eggert S.L., Kolka R.K., 2012. Methylmercury declines in a boreal peatland when experimental sulfate deposition decreases. Environ. Sci. Technol. 46, 6663-6671.

Dittman J.A., Driscoll C.T., 2009. Factors influencing changes in mercury concentrations in lake water and yellow perch (Perca flavescens) in Adirondack lakes. Biogeochemistry 93, 179-196.

Downey D.M., French C.R., Odom M., 1994. Low cost limestone treatment of acid sensitive trout streams in the Appalachian Mountains of Virginia. Water Air Soil Pollut. 77, 49-77. 
Driscoll C.T., Ayling W.A., Fordham G.F., Oliver L.M., 1989. Chemical response of lakes treated with $\mathrm{CaCO}_{3}$ to reacidification. Can. J. Fish. Aquat. Sci. 46, 258-267.

Driscoll C.T., Driscoll K.M., Roy K.M., Dukett J., 2007. Changes in the chemistry of lakes in the Adirondack Region of New York following declines in acidic deposition. Appl. Geochem. 22, 1181-1188.

Driscoll C.T., Lawrence G.B., Bulger A.J., Butler T.J., Cronan C.S., Eagar C., Lambert K.F., Likens G.E., Stoddard J.L., Weathers K.C., 2001. Acidic deposition in the northeastern United States: sources and inputs, ecosystem effects, and management strategies. BioScience 51, 180-198.

Driscoll C.T., Mason R.P., Chan H.M., Jacob D.J., Pirrone N., 2013. Mercury as a global pollutant: sources, pathways, and effects. Environ. Sci. Technol. 47, 4967-4983.

Driscoll C.T., Yan C., Schofield C.L., Munson R., Holsapple J., 1994. The mercury cycle and fish in the Adirondack lakes. Environ. Sci. Technol. 28, 136A-143A.

Duchesne L., Ouimet R., Houle D., 2002. Basal area growth of sugar maple in relation to acid deposition, stand health, and soil nutrients. J. Environ. Qual. 31, 1667-1683.

Duchesne L., Ouimet R., Moore D.L., Paquin R., 2005. Changes in structure and composition of maplebeech stands following sugar maple decline in Quebec, Canada. For. Ecol. Manage. 208, 223236.

Eggleton M.A., Morgan E.L., Pennington W.L., 1996. Effects of liming on an acid-sensitive southern Appalachian stream. Restor. Ecol. 4, 247-263.

Enge E., Kroglund F., 2011. Population density of Brown trout (Salmo trutta) in extremely dilute water qualities in mountain lakes in southwestern Norway. Water Air Soil Pollut. 219, 489-499.

Evans C.D., Jones T.G., Burden A., Ostle N., Zielinski P., Cooper M.D.A., Peacock M., Clark J.M., Oulehle F., Cooper D., Freeman C., 2012. Acidity controls on dissolved organic carbon mobility in organic soils. Global Change Biol. 18, 3317-3331.

Evers D.C., Han Y.-J., Driscoll C.T., Kamman N.C., Goodale M.W., Lambert K.F., Holsen T.M., Chen C.Y., Clair T.A., Butler T., 2007. Biological mercury hotspots in the northeastern United States and southeastern Canada. Bioscience 57, 29-43.

Findlay D.L., 2003. Response of phytoplankton communities to acidification and recovery in Killarney Park and the experimental lakes area, Ontario. Ambio XXXII, 190-195.

Fuss C.B., Driscoll C.T., 2015. Recovery from chronic and snowmelt acidification: Long-term trends in stream and soil water chemistry at the Hubbard Brook Experimental Forest, New Hampshire, USA. J. Geophys. Res. (G Biogeosci.) 120, 2360-2374.

Gabriel M.C., Williamson D.G., 2004. Principal biogeochemical factors affecting the speciation and transport of mercury through the terrestrial environment. Environ. Geochem. Health 26, 421434.

Gerson J.R., Driscoll C.T., Roy K.M., In Press. Patterns of nutrient dynamics in Adirondack lakes recovering from acid deposition. Ecol. Appl.

Gilmour C.C., Henry E.A., 1991. Mercury methylation in aquatic systems affected by acid deposition. Environ. Pollut. 71, 131-169.

Gloss S.P., Schofield C.L., Sherman R.E., 1988. An evaluation of the New York State lake liming data and the application of models from the Scandinavian lakes to Adirondack lakes. Water Air Soil Pollut. 41, 241-278.

Groffman P.M., Fisk M.C., 2011. Calcium constrains plant control over forest ecosystem nitrogen cycling. Ecology 92, 2035-2042.

Groffman P.M., Fisk M.C., Driscoll C.T., Likens G.E., Fahey T.J., Eagar C., Pardo L.H., 2006. Calcium additions and microbial nitrogen cycle processes in a northern hardwood forest. Ecosystems 9 , 1289-1305. 
Håkanson L., Nilsson Å., Andersson T., 1988. Mercury in fish in Swedish lakes. Environ. Pollut. 49, 145162.

Hall L.W., Killen J., W.D., Fischer S.A., Ziegenfuss M.C., Anderson R.D., Klauda R.J., 1994. The efficacy of a limestone doser to mitigate stream acidification in a Maryland coastal plain stream: implications for migratory fish species. Environ. Monit. Assess. 31, 233-257.

Hallet R.A., Bailey S.W., Horsley S.B., Long R.P., 2006. Influence of nutrition and stress on sugar maple at a regional scale. Can. J. For. Res. 36, 2235-2246.

Halman J.M., Schaberg P.G., Hawley G.J., Eagar C., 2008. Calcium addition at the Hubbard Brook Experimental Forest increases sugar storage, antioxidant activity and cold tolerance in red spruce. Tree Physiol. 28, 855-862.

Hames R.S., Rosenberg K.V., Lowe J.D., Barker S.E., Dhondt A.A., 2002. Adverse effects of acid rain on the distribution of the wood thrush Hylocichla mustelina in North America. Proc. Natl. Acad. Sci. U.S.A. 99, 11235-11240.

Hawley G.J., Schaberg P.G., Eager C., Borer C.H., 2006. Calcium addition at the Hubbard Brook Experimental Forest reduced winter injury to red spruce in a high-injury year. Can. J. For. Res. 36, 2544-2549.

Hazlett P.W., Curry J.M., Weldon T.P., 2011. Assessing decadal change in mineral soil cation chemistry at the Turkey Lakes Watershed. Soil Sci. Soc. Am. J. 75, 287-305.

Hesthagen T., Svensson B.S., Fiske P., 2011. Liming restores Atlantic salmon (Salmo salar) populations in acidified Norwegian rivers. Can. J. Fish. Aquat. Sci. 68, 224-231.

Higgs E., Falk D.A., Guerrini A., Hall M., Harris J., Hobbs R.J., Jackson S.T., Rhemtulla J.M., Throop W., 2014. The changing role of history in restoration ecology. Front. Ecol. Environ. 12, 499-506.

Hindar A., Kroglund F., Lydersen E., Skiple A., Hogberget R., 1996. Liming of wetlands in the acidified Lake Røynelandsvatn catchment in southern Norway: effects on stream water chemistry. Can. J. Fish. Aquat. Sci. 53, 985-993.

Holdsworth A.R., Frelich L.E., Reich P.B., 2008. Litter decomposition in earthworm-invaded northern hardwood forests: Role of invasion degree and litter chemistry. Ecoscience 15, 536-544.

Hongve D., Haaland S.I., Riise G., Blakar I., Norton S., 2012. Decline of acid rain enhances mercury concentrations in fish. Environ. Sci. Technol. 46, 2490-2491.

Horsley S.B., Bailey S.W., Ristau T.E., Long R.P., Hallet R.A., 2008. Linking environmental gradients, species composition, and vegetation indicators of sugar maple health in the northeastern United States. Can. J. For. Res. 38, 1761-1774.

Hudy M., Downey D.M., Bowman D.W., 2000. Successful restoration of an acidified native brook trout stream through mitigation with limestone sand. N. Am. J. Fish. Manage. 20, 453-466.

Ivahnenko T.I., Renton J.J., Rauch H.W., 1988. Effects of liming on water quality of two streams in West Virginia. Water Air Soil Pollut. 41, 331-357.

Jardine T.D., Kidd K.A., O'Driscoll N., 2013. Food web analysis reveals effects of pH on mercury bioaccumulation at multiple trophic levels in streams. Aquat. Toxicol. 132, 46-52.

Jeziorski A., Paterson A.M., Smol J.P., 2012. Crustacean zooplankton sedimentary remains from calciumpoor lakes: complex responses to threshold concentrations. Aquat. Sci. 74, 121-131.

Jeziorski A., Yan N.D., Paterson A.M., DeSellas A.M., Turner M.A., Jeffries D.S., Keller B., Weeber R.C., McNicol D.K., Palmer M.E., Mclver K., Arseneau K., Ginn B.K., Cumming B.F., Smol J.P., 2008. The widespread threat of calcium decline in fresh waters. Science 322, 1374-1377.

Johnson A.H., Moyer A.J., Bedison J.E., Richter S.L., Willig S.A., 2008. Seven decades of calcium depletion in organic horizons of Adirondack forest soils. Soil Sci. Soc. Am. J. 72, 1824-1830.

Johnson C.E., Driscoll C.T., Blum J.D., Fahey T.J., Battles J.J., 2014. Soil chemical dynamics after calcium silicate addition to a northern hardwood forest. Soil Sci. Soc. Am. J. 78, 1458-1468. 
Johnson C.E., Driscoll C.T., Siccama T.G., Likens G.E., 2000. Element fluxes and landscape position in a northern hardwood forest watershed ecosystem. Ecosystems 3, 159-184.

Josephson D.C., Robinson J.M., Chiotti J., Jirka K.J., Kraft C.E., 2014. Chemical and biological recovery from acid deposition within the Honnedaga Lake watershed, New York, USA. Environ. Monit. Assess. 186, 4391-4409.

Juice S.M., Fahey T.J., Siccama T.G., Driscoll C.T., Denny E.G., Eagar C., Cleavitt N.L., Minocha R., Richardson A.D., 2006. Response of sugar maple to calcium addition to northern hardwood forest. Ecology 87, 1267-1280.

Keener A.L., Sharpe W.E., 2005. The effects of doubling limestone sand applications in two acidic southwestern Pennsylvania streams. Restor. Ecol. 13, 108-119.

Keller W., Yan N.D., Gunn J.M., Heneberry J., 2007. Recovery of acidified lakes: lessons from Sudbury, Ontario, Canada. Water Air Soil Pollut: Focus 7, 317-322.

Keller W., Yan N.D., Howell T., Molot L.A., Taylor W.D., 1992. Changes in zooplankton during the experimental neutralization and early reacidification of Bowland Lake, Near Sudbury, Ontario. Can. J. Fish. Aquat. Sci. 49.

Kelly C.A., Rudd J.W.M., Hesslein R.H., Schindler D.W., Dillon P.J., Driscoll C.T., Gherini S.A., Hecky R.E., 1987. Prediction of biological acid neutralization in acid-sensitive lakes. Biogeochemistry 3 , 129-140.

Kowalick R.A., Cooper C.M., Evans C.D., Ormerod S.J., 2007. Acidic episodes retard the biological recovery of upland British streams from chronic acidification. Global Change Biol. 13, 24392452.

Kreutzer K., 1995. Effects of forest liming on soil processes. Plant Soil 168-169, 447-470.

Lawrence G.B., Burns D.A., Stoddard J.L., Baldigo B.P., Porter J.H., Thompson A.W., David M.B., Lovett G.M., Murdoch P.S., 1999. Soil calcium status and the response of stream chemistry to changing acidic deposition rates. Ecol. Appl. 9, 1059-1072.

Lawrence G.B., Dukett J.E., Houck N., Snyder P., Capone S.B., 2013. Increases in dissolved organic carbon accelerate loss of toxic Al in Adirondack lakes recovering from acidification. Environ. Sci. Technol. 47, 7095-7100.

Lawrence G.B., Hazlett P.W., Fernandez I.J., Ouimet R., Bailey S.W., Shortle W.C., Smith K.T., Antidormi M.R., 2015a. Declining acidic deposition begins reversal of forest-soil acidification in the Northeastern U.S. and Eastern Canada. Environ. Sci. Technol. 49, 13103-13111.

Lawrence G.B., Lapenis A.G., Berggren D., Aparin B.F., Smith K.T., Shortle W.C., Bailey S.W., Varlyguin D.L., Babikov B., 2005. Climate dependency of tree growth suppressed by acid deposition effects on soils in Northwest Russia. Environ. Sci. Technol. 39, 2004-2010.

Lawrence G.B., Roy K.M., Baldigo B.P., Simonin H.A., Capone S.B., Sutherland J.S., Nierswicki-Bauer S.A., Boylen C.W., 2008. Chronic and episodic acidification of Adirondack streams from acid rain in 2003-2005. J. Environ. Qual. 37, 2264-2274.

Lawrence G.B., Shortle W.C., David M.B., Smith K.T., Warby R.A.F., Lapenis A.G., 2012. Early indications of soil recovery from acidic deposition in U.S. red spruce forests. Soil Sci. Soc. Am. J. 76, 14071417.

Lawrence G.B., Simonin H.A., Baldigo B.P., Roy K.M., Capone S.B., 2011. Changes in the chemistry of acidifed Adirondack streams from the early 1980s to 2008. Environ. Pollut. 159, 2750-2758.

Lawrence G.B., Sullivan T.J., Burns D.A., Bailey S.W., Cosby B.J., Dovciak M., Ewing H.A., McDonnell T.C., Minocha R., Quant J., Rice K.C., Siemion J., Weathers K.C. 2015b. Acidic deposition along the Appalachian Trail corridor and its effects on acid-sensitive terrestrial and aquatic resources: Results of the Appalachian Trail MEGA-transect atmospheric deposition effects study. Natural Resource Report NPS/NRSS/ARD/NRR-2015/996. National Park Service, Fort Collins, Colorado. 
Lawrence G.B., Sutherland J.W., Boylen C.W., Nierzwicki-Bauer S.A., Momen B., Baldigo B.P., Simonin H.A., 2007. Acid rain effects on aluminum mobilization clarified by inclusion of strong organic acids. Environ. Sci. Technol. 41, 93-98.

LeFevre S.R., Sharpe W.E., 2002. Acid stream water remediation using limestone sand on Bear Run in southwestern Pennsylvania. Restor. Ecol. 10, 223-236.

Likens G.E., Bormann F.H., Pierce R.S., Eaton J.S., Johnson N.M. Biogeochemistry of a Forested Ecosystem. NY Springer-Verlag Inc. , 1977.

Likens G.E., Buso D.C., 2012. Dilution and the elusive baseline. Environ. Sci. Technol. 46, 4382-4387.

Likens G.E., Driscoll C.T., Buso D.C., 1996. Long-term effects of acid rain: response and recovery of a forest ecosystem. Science 272, [d]244-246.

Long R.P., Bailey S.W., Horsley S.B., Hall T.J., Swistock B.R., DeWalle D.R., 2015. Long-term effects of forest liming on soil, soil leachate, and foliage chemistry in northern Pennsylvania. Soil Sci. Soc. Am. J. 79, 1223-1236.

Long R.P., Horsley S.B., Hall G.F., 2011. Long-term impact of liming on growth and vigor of northern hardwoods. Can. J. For. Res. 41, 1295-1307.

Long R.P., Horsley S.B., Hallet R.A., Bailey S.W., 2009. Sugar maple growth in relation to nutrition and stress in the Northeastern United States. Ecol. Appl. 19, 1454-1466.

Long R.P., Horsley S.B., Lilja P.R., 1997. Impact of forest liming on growth and crown vigor of sugar maple and associated hardwoods Can. J. For. Res. 27, 1560-1573.

Lovett G.M., Arthur M.A., Crowley K.F., 2015. Effects of calcium on the rate and extent of litter decomposition in a northern hardwood forest. Ecosystems. 11/2015, DOI:10.10007/S10021015-9919-0.

McCay T.S., Cardelus C.L., Neatrour M.A., 2013. Rate of litter decay and litter macroinvertebrates in limed and unlimed forests of the Adirondack Mountains, USA. For. Ecol. Manage. 304, 254-260.

McClurg S.E., Petty J.T., Mazik P.M., Clayton J.L., 2007. Stream ecosystem response to limestone treatment in acid impacted watersheds of the Allegheny Plateau. Ecol. Appl. 17, 1087-1104.

McHale M.R., Murdoch P.S., Burns D.A., Lawrence G.B., 2007. Factors controlling aluminum release after a clearcut in a forested watershed with calcium-poor soils. Biogeochemistry 84, 311-331.

Melvin A.M., Lichstein J.W., Goodale C.L., 2013. Forest liming increases forest floor carbon and nitrogen stocks in a mixed hardwood forest. Ecol. Appl. 23, 1962-1975.

Menendez R., Clayton J.L., Zurbuch P.E., 1996. Chemical and fishery responses to mitigative liming of an acidic stream, Dogway Fork, West Virginia. Restor. Ecol. 4, 220-233.

Minocha R., Long S., 2004. Effects of aluminum on organic acid metabolism and secretion by red spruce cell suspension cultures and the reversal of Al effects on growth and polyamine metabolism by exogenous organic acids. Tree Physiol. 24, 55-64.

Molot L.A., Dillon P.J., Booth G.M., 1990a. Whole-lake and nearshore water chemistry in Bowland Lake, before and after treatment with $\mathrm{CaCO}_{3}$. Can. J. Fish. Aquat. Sci. 47, 412-421.

Molot L.A., Heintsch L., Nicholls K.H., 1990b. Response of phytoplankton in acidic lakes in Ontario to whole-lake neutralization. Canadian Journal of Fisheries and Aquatic Research 47, 422-431.

Momen B., Lawrence G.B., Nierzwicki-Bauer S.A., Sutherland J.W., Eichler L., Harrison J.P., Boylen C.W., 2006. Trends in summer chemistry linked to productivity in lakes recovering from acid deposition in the Adirondack Region of New York. Ecosystems 9, 1306-1317.

Moore J.-D., 2014. Short-term effect of forest liming on eastern red-backed salamander (Plethodon cinereus). For. Ecol. Manage. 318, 270-273.

Moore J.-D., Ouimet R., Bohlen P.J., 2013. Effects of liming on survival and reproduction of two potentially invasive earthworm species in a northern forest podzol. Soil Biol. Biochem. 64, 174180. 
Moore J.-D., Ouimet R., Duchesne L., 2012. Soil and sugar maple response 15 years after dolomitic lime application. For. Ecol. Manage. 281, 130-139.

Moore J.-D., Ouimet R., Long R.P., Bukaveckas P.A., 2015. Ecological benefits and risks arising from liming sugar maple dominated forests in northeastern North America. Environ. Rev. 23, 66-77.

Munthe J., Bodaly R., Branfireun B.A., Driscoll C.T., Gilmour C.C., Harris R., Horvat M., Lucotte M., Malm O., 2007. Recovery of mercury-contaminated fisheries. Ambio 36, 33-44.

Newton R.M., Burns D.A., Blette V.L., Driscoll C.T., 1996. Effect of whole catchment liming on the episodic acidification of two Adirondack streams. Biogeochemistry 32, 299-322.

Nezat C.A., Blum J.D., Driscoll C.T., 2010. Patterns of $\mathrm{Ca} / \mathrm{Sr}$ and ${ }^{87} \mathrm{Sr} /{ }^{86} \mathrm{Sr}$ variation before and after a whole watershed $\mathrm{CaSiO} 3$ addition at the Hubbard Brook Experimental Forest, USA. Geochim. Cosmoschim Acta 74, 3129-3142.

Nolet P., Delagrange S., Bannon K., Messier C., Kneeshaw D., 2015. Liming has a limited effect on sugar maple-American beech dynamics compared with beech sapling elimination and canopy opening. Can. J. For. Res. 45, 1376-1386.

Oste L.A., Temminghoff J.M., van Riemsdijk W.H., 2002. Solid-solution partitioning of organic matter in soils as influenced by an increase in pH or Ca concentration. Environ. Sci. Technol. 36, 208-214.

Pabian S.E., Brittingham M.C., 2007. Terrestrial liming benefits birds in an acidified forest in the Northeast. Ecol. Appl. 17, 2184-2194.

Parkman H., Munthe J., 1998. Wood ash and dolomite treatments of catchment areas: effects on mercury in run-off water. Scand. J. For. Res. Suppl. 2, 33-42.

Persson T., Rudebeck A., Wiren A., 1995. Pools and fluxes of carbon and nitrogen in 40-year-old forest liming experiments in Southern Sweden. Water Air Soil Pollut. 85, 901-906.

Pirrone N., Cinnirella S., Feng X., Finkelman R., Friedli H., Leaner J., Mason R., Mukherjee A., Stracher G., Streets D., 2010. Global mercury emissions to the atmosphere from anthropogenic and natural sources. Atmos. Chem. Phys. 10, 5951-5964.

Poleo A.B.S., Lydersen E., Rosseland B.O., Kroglund F., Salbu B., Vogt R.D., Kvellestad A., 1994. Increased mortality of fish due to changing Al chemistry of mixing zones between limed streams and acidic tributaries. Water Air Soil Pollut. 75, 339-351.

Rask M., Jones R.I., Järvinen M., Paloheimo A., Salonen M., Syväranta J., Verta M., 2007. Changes in fish mercury concentrations over 20 years in an acidified lake subject to experimental liming. Appl. Geochem. 22, 1229-1240.

Reid C., Watmough S.A., 2013. Evaluating the effects of liming and wood-ash treatment on forest ecosystems through systematic meta-analysis. Can. J. For. Res. 44, 867-885.

Rice K.C., Herman J.S., 2012. Acidification of Earth: an assessment across mechanisms and scales. Appl. Geochem. 27, 1-14.

Schaberg P.G., Minocha R., Long S., Halman H.M., Hawley G.J., Eagar C., 2011. Calcium addition at the Hubbard Brook Experimental Forest increases the capacity for stress tolerance and carbon capture in red spruce (Picea rubens) trees during the cold season. Trees 25, 1053-1061.

Schaberg P.G., Tilley J.W., Hawley G.J., DeHayes D.H., Bailey S.W., 2006. Associations of calcium and aluminum with the growth and health of sugar maple trees in Vermont. For. Ecol. Manage. 223, 159-169.

Schaffner W.R., 1989. 1975. Effects of neutralization and addition of brook trout (Salvelinus fontinalis) on the limnetic zooplankton communities of two acidic lakes. Can. J. Fish. Aquat. Sci. 46, 295305.

Scheider W.A., Adamski J., Paylor M. Reclamation of acidified lakes near Sudbury, Ontario, Ontario Ministry of the Environment Report, Rexdale, ON, $129 \mathrm{p}$.

Schneider S.C., 2011. Impact of calcium and TOC on biological acidification assessment in Norwegian rivers. Sci. Total Environ. 409, 1164-1171. 
Shastri Y., Diwekar U., 2008. Optimal control of lake pH for mercury bioaccumulation control. Ecol. Model. 216, 1-17.

Simmons K.R., Cieslewicz P.G., 1996. Limestone treatment of Whetsone Brook, Massachusetts. I. Treatment methodology and water chemistry changes during treatment. Restor. Ecol. 4, 264272.

Simmons K.R., Cieslewicz P.G., Zajicek K., 1996. Limestone treatment of Whetstone Brook, Massachusetts. II. Changes in the brown trout (Salmo trutta) and brook trout (Salvelinus fontinalis) fishery. Restor. Ecol. 4, 273-283.

Simmons K.R., Doyle K., 1996. Limestone treatment of Whetstone Brook, Massachusetts. III. Changes in the invertebrate fauna. Restor. Ecol. 4, 284-292.

Sloan R., Schofield C., 1983. Mercury levels in brook trout (Salvelinus fontinalis) from selected acid and limed Adirondack lakes. Northeast. Environ. Sci. 2, 165-170.

Sterling S.M., Angelidis C., Armstrong M., Biagi K.M., Clair T.A., Jackson N., Breen A., 2014. Terrestrial liming to promote Atlantic Salmon recovery in Nova Scotia - approaches needed and knowledge gained after a trial application. Hydrol. Earth Syst. Sci. Discuss. 11, 10117-10156.

Strock K.E., Nelson S.J., Kahl J.S., Saros J.E., McDowell W.H., 2014. Decadal trends reveal recent acceleration in the rate of recovery from acidification in the Northeastern U.S. Environ. Sci. Technol. 48, 4681-4689.

Sullivan T.J., Lawrence G.B., Bailey S.W., McDonnell T.C., Beier C.M., Weathers K.C., McPherson G.T., Bishop K., 2013. Effects of acidic deposition and soil acidification on sugar maple trees in the Adirondack Mountains, New York. Environ. Sci. Technol. 47, 12687-12694.

Sverdrup H., Warfvinge P., 1985. A reacidification model for acidified lakes neutralized with calcite. Water Resour. Res. 21, 1374-1380.

Traaen T.S., Frogner T., Hindar A., Kleiven E., Lande A., Wright R.F., 1997. Whole-catchment liming at Tjonnstrond, Norway: and 11-year record. Water, Air, and Soil Pollution 94, 163-180.

Waller K., Driscoll C.T., Lynch J., Newcomb D., Roy K.M., 2012. Long-term recovery of lakes in the Adirondack region of New York to decreases in acidic deposition. Atmos. Environ. 46, 56-64.

Warby R.A.F., Johnson C.E., Driscoll C.T., 2005. Chemical recovery of surface waters across the northeastern United States from reduced inputs of acidic deposition: 1984-2001. Environ. Sci. Technol. 39, 6548-6554.

Warby R.A.F., Johnson C.E., Driscoll C.T., 2009. Continuing acidification of organic soils across the Northeastern USA: 1984-2001. Soil Sci. Soc. Am. J. 73, 274-284.

Watmough S.A., Dillon P.J., 2004. Major element fluxes from a coniferous catchment in central Ontario, 1983-1999. Biogeochemistry 67, 369-398.

Watmough S.A., Meadows M.J., 2014. Do earthworms have a greater influence on nitrogen dynamics than atmospheric nitrogen deposition? Ecosystems 17, 1257-1270.

Weatherly N.S., Rutt G.P., Thomas S.P., Ormerod S.J., 1991. Liming acid streams: aluminium toxicity to fish in mixing zones. Water Air Soil Pollut. 55, 345-353.

Wright R.F., Larssen T., Camarero I.L., Cosby B.J., Ferrier R.C., Helliwell R., Forsius M., Jenkins A., Kopacek J., Maier V., Moldan F., Posch M., Rogora M., Schopp W., 2005. Recovery of acidified European surface waters. Environ. Sci. Technol. 39, 64a-72a.

Yanai R.D., Siccama T.G., Arthur M.A., Federer C.A., Friedland A.J., 1999. Accumulation and depletion of base cations in forest floors in the northeastern United States. Ecology 80, 2774-2787.

Yavitt J.B., Fahey T.J., 1996. Peat and solution chemistry responses to $\mathrm{CaCO}_{3}$ application in wetlands next to Woods Lake, New York. Biogeochemistry 32, 245-263.

Zurbuch P.E., Menendez R., Clayton J.L., 1996. Limestone neutralization of Dogway Fork, West Virginia, by means of a rotary-drum system. Restor. Ecol. 4, 206-219. 
Liming is no longer needed to prevent further damage from acidic deposition. However, recovery of calcium-depleted ecosystems is sluggish and the conditions of full recovery remain uncertain. Whole-watershed liming may accelerate recovery in terrestrial and aquatic ecosystems where recovery is being impeded by low availability of calcium.

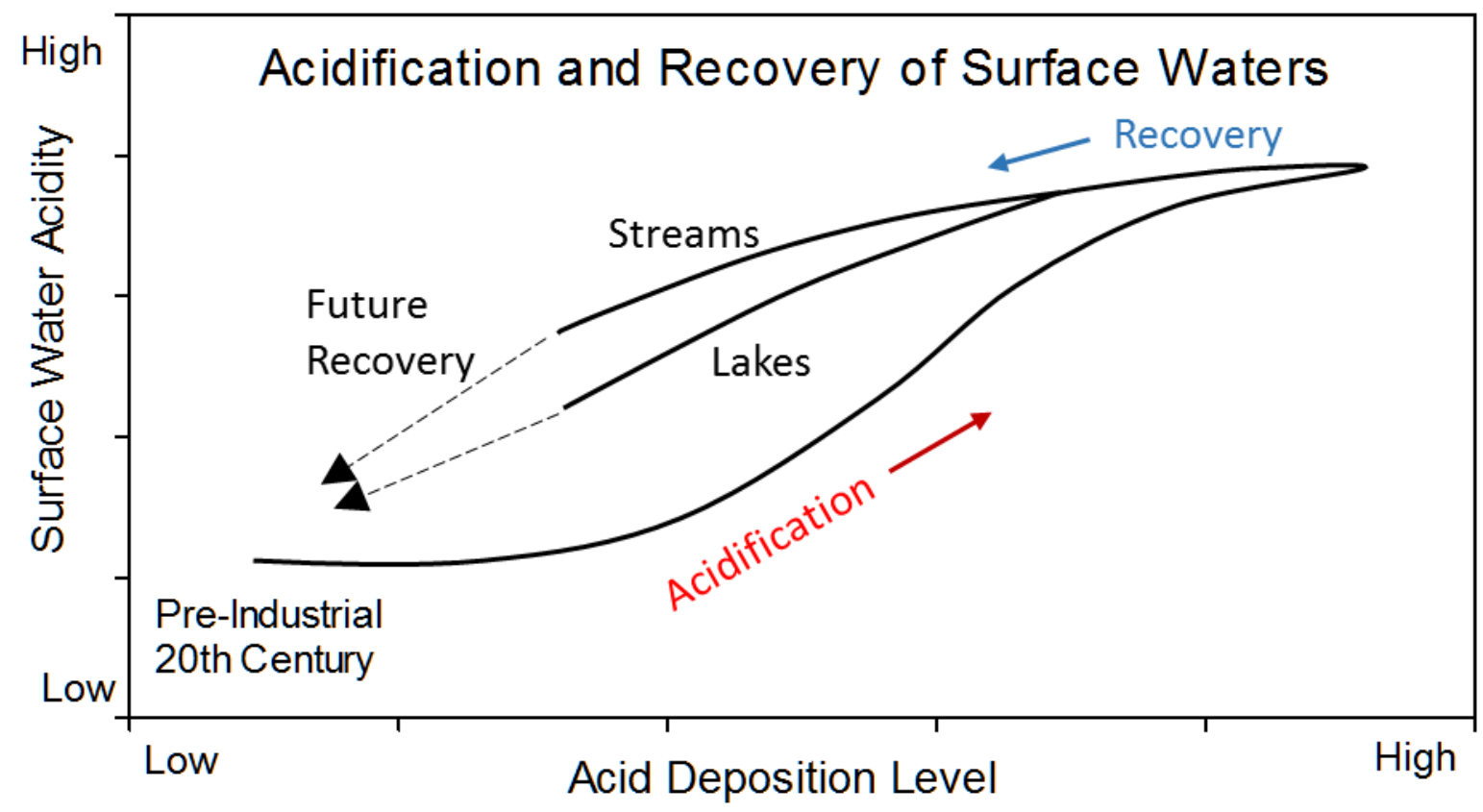

